\title{
READY NOW:
}

FIRST ANNUAL ISSUE

\section{International Bibliography of Theatre: 1982}

Published by The Theatre Research Data Center at Brooklyn College Sponsored by The American Society for Theatre Research

The International Association of Libraries and Museums of the Performing Arts

In cooperation with The International Federation for Theatre Research

\section{ORDER NOW >}

TRDC, THE PUBLISHING CENTER 625 BROADWAY, NEW YORK 10012

INSTITUTIONS $\$ 65$ INDIVIDUALS $\$ \mathbf{\$ 5 0}$ 


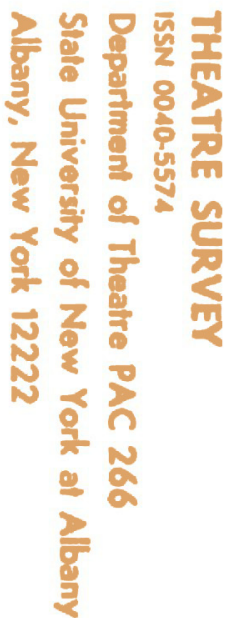

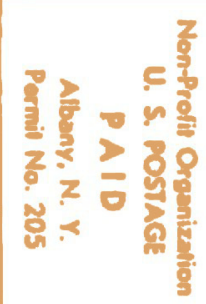

